Instrumental Achievements

\title{
Crystal Structure of 3-Ethoxy-6-cyano-5-[2-(4-ethoxycarbonyl)thiazolyl]pyridine
}

\author{
Yoshihiro Yoxoyama*, Yuji OHashi*, Kazuyuki UmemUrA** and Juji YoshimURA** \\ *Department of Chemistry, Tokyo Institute of Technology, O-okayama, Tokyo 152, Japan \\ **Iwaki Meisei University, Chuodai-ïno, Iwaki 970, Japan
}

Nosiheptide ${ }^{1}$ is a peptide antibiotic whose acid hydrolysis gave heterocyclic compounds called Fragments A, $\mathrm{C}, \mathrm{D}, \mathrm{E}$ and two kinds of amino acids. Among them, Fragment $A$ has a pyridine skeleton substituted with three thiazole rings. In the course of the synthesis of Fragment A, cyanation of 3-ethoxy-5-22-(4-ethoxycarbonyl)thiazolyl]pyridine (1) by Reissert-Henze method gave two isomers (main, mp. $158-159^{\circ} \mathrm{C}$; minor, mp. $159.5-$ $160.5^{\circ} \mathrm{C}$ ). The structures of them are deduced to be 2cyano (2) and 6-cyano (3) derivatives, but they couldn't be distinguished by usual analytical methods. The minor compound can be separated by silica gel column chromatography and the single crystal was obtained by slow recrystallization from an ethanol/ethyl acetate solution covered with hexane vapor. Here, we wish to report that the minor compound was determined to be

Table 1 Crystal data and experimental details

\begin{tabular}{|c|c|}
\hline Formula & $\mathrm{C}_{14} \mathrm{H}_{13} \mathrm{~N}_{3} \mathrm{O}_{3} \mathrm{~S}$ \\
\hline Formula weight & 303.33 \\
\hline Temperature & $173 \mathrm{~K}$ \\
\hline Crystal size & $0.40 \times 0.30 \times 0.05 \mathrm{~mm}$ \\
\hline Crystal color & transparent \\
\hline Crystal description & plate \\
\hline Crystal system & triclinic \\
\hline Space group & $P 1 \quad Z=2$ \\
\hline$a$ & $9.685(2) \AA$ \\
\hline$b$ & $16.718(2) \AA$ \\
\hline$c$ & $4.4015(4) \AA$ \\
\hline$\alpha$ & $91.51(1)^{\circ}$ \\
\hline$\beta$ & $94.12(1)^{\circ}$ \\
\hline$\gamma$ & $99.555(5)^{\circ}$ \\
\hline $\boldsymbol{V}$ & $700.5(2) \AA^{3}$ \\
\hline$D_{\mathrm{x}}$ & $1.438 \mathrm{Mg} \mathrm{m}^{-3}$ \\
\hline Radiation & $0.71069 \AA\left(\mathrm{MoK}_{\alpha}\right)$ \\
\hline Diffractometer & Rigaku R-AXIS-II-CS \\
\hline Monochromator & graphite \\
\hline No. of reflections measured & 5931 \\
\hline No. of reflections observed $[>2 \sigma(I)]$ & 2379 \\
\hline No. of parameters & 229 \\
\hline$R(F)$ & 0.0500 \\
\hline$w R(F)$ & 0.1354 \\
\hline Structure determination & TEXSAN $^{2}$ \\
\hline Refinement & SHELX-933 \\
\hline
\end{tabular}<smiles>CCCOc1cncc(-c2nc(C(=O)OCC)cs2)c1</smiles><smiles>CCOc1cc(-c2nc(C(=O)OC(C)(C)C)cs2)cnc1C#N</smiles><smiles>CCOc1cnc(C#N)c(-c2nc(C(=O)OC(C)(C)C)cs2)c1</smiles>

Scheme 1 Synthetic route.

Table 2 Positional and equivalent isotropic thermal parameters for non-hydrogen atoms

\begin{tabular}{ccccc}
\hline Atom & $x$ & $y$ & $z$ & $U_{\text {eq }}$ \\
\hline S1 & $0.67500(5)$ & $0.15741(3)$ & $0.9102(1)$ & 0.0362 \\
O1 & $0.3531(2)$ & $0.41981(9)$ & $0.2237(4)$ & 0.0390 \\
O2 & $0.2271(2)$ & $0.1459(1)$ & $1.3144(4)$ & 0.0430 \\
O3 & $0.3160(2)$ & $0.0333(1)$ & $1.4294(4)$ & 0.0488 \\
N1 & $0.7092(2)$ & $0.3893(1)$ & $0.3387(5)$ & 0.0373 \\
N2 & $0.9363(2)$ & $0.2850(1)$ & $0.6905(6)$ & 0.0521 \\
N3 & $0.4335(2)$ & $0.1980(1)$ & $0.9538(4)$ & 0.0302 \\
C1 & $0.5937(2)$ & $0.4173(1)$ & $0.2480(6)$ & 0.0359 \\
C2 & $0.4606(2)$ & $0.3846(1)$ & $0.3382(5)$ & 0.0326 \\
C3 & $0.4489(2)$ & $0.3200(1)$ & $0.5281(5)$ & 0.0314 \\
C4 & $0.5698(2)$ & $0.2890(1)$ & $0.6276(5)$ & 0.0296 \\
C5 & $0.6974(2)$ & $0.3265(1)$ & $0.5253(5)$ & 0.0319 \\
C6 & $0.2124(2)$ & $0.3864(1)$ & $0.3033(7)$ & 0.0411 \\
C7 & $0.1158(3)$ & $0.4415(2)$ & $0.1771(7)$ & 0.0426 \\
C8 & $0.8302(2)$ & $0.3023(1)$ & $0.6195(6)$ & 0.0392 \\
C9 & $0.5519(2)$ & $0.2195(1)$ & $0.8279(5)$ & 0.0303 \\
C10 & $0.4388(2)$ & $0.1308(2)$ & $1.1221(5)$ & 0.0309 \\
C11 & $0.5610(2)$ & $0.1001(1)$ & $1.1241(5)$ & 0.0346 \\
C12 & $0.3212(2)$ & $0.0966(1)$ & $1.3039(5)$ & 0.0337 \\
C13 & $0.1097(3)$ & $0.1232(2)$ & $1.5024(7)$ & 0.0514 \\
C14 & $-0.0228(3)$ & $0.1092(2)$ & $1.3008(8)$ & 0.0622 \\
\hline & & & &
\end{tabular}

$U_{\mathrm{eq}}=(1 / 3) \Sigma_{i} \Sigma_{j} U_{i j} a_{i}^{*} a_{j}^{*}\left(a_{i} \cdot a_{j}\right)$. 


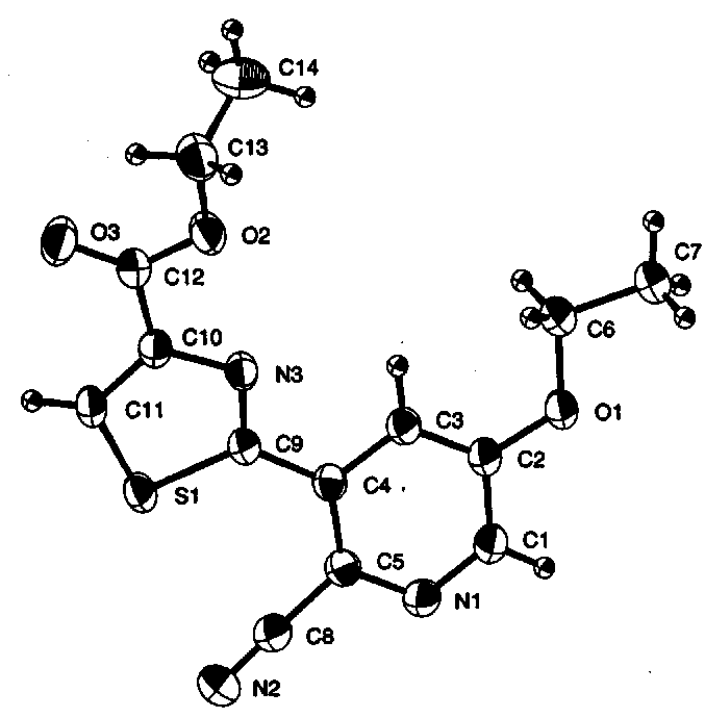

Fig. 1 ORTEP ${ }^{4}$ drawing with the numbering of the atoms. Thermal ellipsoids scaled to enclose $50 \%$ probability.

6-cyanate by X-ray analysis.

Crystal and experimental data are given in Table 1 and the final atomic parameters for non-hydrogen atoms are listed in Table 2. All non-hydrogen atoms were anisotropically refined. All hydrogen atoms were located on a difference Fourier map and isotropically refined. The molecular structure drawn by ORTEP ${ }^{4}$ with atomic numbering is shown in Fig. 1 and indicates that the minor compound is 6-cyanate. Since the torsion angles are almost $0^{\circ}$ or $180^{\circ}(\mathrm{C} 7-\mathrm{C} 6-\mathrm{O} 1-\mathrm{C} 2=$ $173.9(2)^{\circ}, \mathrm{C} 6-\mathrm{O} 1-\mathrm{C} 2-\mathrm{C} 3=-0.9(3)^{\circ}, \mathrm{C} 3-\mathrm{C} 4-\mathrm{C} 9-$ $\mathrm{N} 3=-12.7(3)^{\circ}, \mathrm{N} 3-\mathrm{C} 10-\mathrm{Cl} 2-\mathrm{O} 2=-9.4(3)^{\circ}, \mathrm{Cl} 10-\mathrm{Cl} 2$ $\left.\mathrm{O} 2-\mathrm{C} 13=-176.0(2)^{\circ}\right)$ except for the terminus of the ethoxycarbonyl group $\left(\mathrm{Cl2}-\mathrm{O} 2-\mathrm{C} 13-\mathrm{C} 14=-116.8(3)^{\circ}\right)$, the molecular structure becomes planar in the crystal structure.

The crystal structure is shown in Fig. 2. The molecules are packed as sheets almost parallel to the (021) plane. The short contacts such as $\mathrm{Cl} \cdots \mathrm{O} 1=3.461(3) \AA$, S1...C14 $=3.508(4) \AA$ and $C 7 \cdots C 7=3.522(5) \AA$ may be

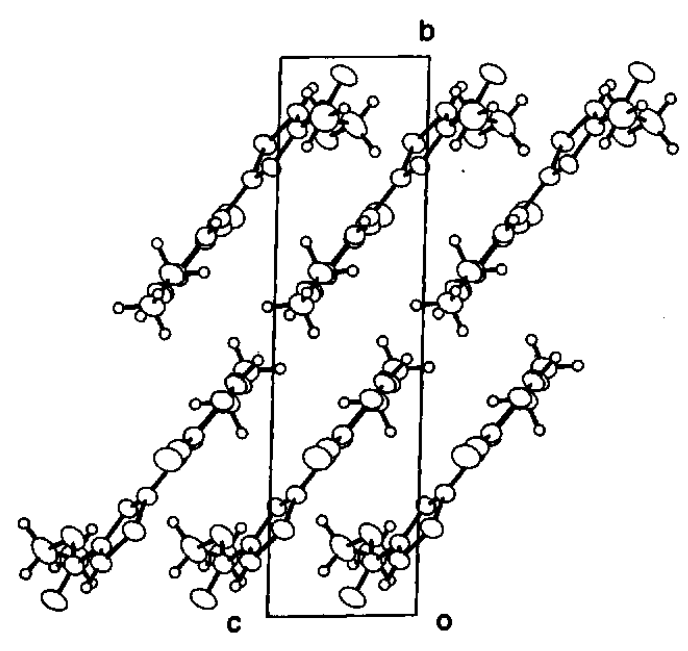

Fig. 2 Crystal structure viewed along $a$ axis.

responsible to the sheet formation. The crystal structure is constructed by stacking the sheets. The distance between the sheets is about $3.5 \AA$. There are two short contacts between the sheets N3...C4=3.305(3) $\AA$ and $\mathrm{N} 3 \cdots \mathrm{C} 14=3.374(5) \AA)$.

\section{References}

1. H. Depire, J. Thomas and A. Brun, Tetrahedron Lett., 1397, 1401 (1977); T. Prange, A. Ducruix and C. Pascard, Nature [London], 265, 6418 (1977); C. Pascard, A. Ducruix, J. Lunel and T. Prange, J: Am. Chem. Soc., 99, 6418 (1977).

2. Molecular Structure Corporation, TEXSAN. TEXRAY Structure Analysis Package (1985).

3. G. M. Sheldrick, SHELX-93 (1993), Program for the refinement of crystal structures. Univ. of Goettingen, Germany.

4. C. K. Johnson, ORTEP II (1976), Report ORNL-5138. Oak Ridge National Laboratory, Tennessee, USA.

(Received February 17, 1997) (Accepted April 28, 1997) 